\title{
O Penhor Rural e a Cedula Rural Pignoraticia
}

\author{
Waldemar Ferreira
}

Pela lei n. 492, de 30 de agosto de 1937, pablicada no Diario Oficial da União, de 1 de setembro de 1937, regulou-se o penhor rural $e$ instituiu-se a cedula rural pignoraticia.

Desnecessario é encarecer a importancia da materia disciplinada no recente diploma legislativo. Criou-se, por via dele, um novo titulo de credito: a cedula rural pignoraticia. Vai entrar ela na circulação economica. Será bem aceita pelos agricultores, comerciantes e banqueiros?

Formule-se a interrogação. Mas procure-se, sobretudo, acreditar o novo titulo, dando-lhe prestancia economica. Sob o prisma juridico, foi ele largamente estudado, no parecer $e$ no substitutivo, que ao projeto, elaborado pela Comissão de Agricultura, de acôrdo com o anteprojeto governamental, apresentou o Deputado Waldemar Ferreira á Comissão de Constituição e Justiça da Camara dos Deputados e esta veiu, afinal, a aprovar, com pequenas modificações, em notas, aqui agora assinaladas, $e$ de redação, introduzidas no texto legal definitivo.

Eis os dois interessantes documentos:

1. Na mensagem, por via da qual encaminhou á Camara dos Deputados o anteprojeto de lei reguladora do penhor rural, na sua dupla modalidade - o agricola e o pecuario, em linhas muito rapidas salientou o sr. Presidente da Republica o que lhe parece indispensavel para a organização do credito agricola, destinado a movimentar os valores da nossa economia rural. "A principal inovação do anteprojeto", escreveu o primeiro magistrado da Nação, 
“consiste no certificado de penhor, transferivel por endosso, visando tornar mais negociavel um titulo que, pelo direito vigente, não se reveste do carateristico de papel bancario, de circulação facil e garantida".

Mas em que tal certificado consiste? Quem o expede? Quais os seus carateristicos? Quais os seus efeitos?

2. A resposta a todas essas interrogações se encontra nos artigos 5 a 9 do anteprojeto, deste teôr:

“Art. 5. - 0 contrato de penhor rural quer seja feito por instrumento publico, quer por instrumento particular, com os requisitos do art. 135 do codigo civil, deverá, para valer contra terceiros, ser transcrito no registro de imoveis da comarca em que estiverem situados os bens apenhados.

“Paragrafo unico. - E' requisito essencial do contrato de penhor rural a indicação do fim a que se destina a quantia emprestada.

“Art. 6. - Feita a transcrição do contrato de penhor, o oficial do registro de imoveis expedirá um certificado do qual constarão as seguintes especificações:

“a) os nomes dos contratantes;

“b) a importancia do debito e o vencimento deste;

“c) a data do contrato;

“d) a identificação, a quantidade e a situação dos bens apenhados, com a indicação precisa do imovel onde se acham;

“e) a data da transcrição.

“Paragrafo unico. - Esse certificado será entregue ao credor.

“Art. 7 - 0 certificado de penhor rural é transferivel por endosso, o qual deverá conter: a data, o nome, o domicilio e a assinatura do endossante e do endossatario. Cada endossatario deverá fazer averbar o ultimo endosso na transcrição do penhor.

"Art. 8. - 0 credor originario ou o ultimo endossatario, quando tenha havido transferencia do certificado, tem, 
em primeiro lugar, ação para excutir o penhor, e, no caso de insuficiencia deste, o devedor principal e todos os endossantes serão responsaveis pessoal e solidariamente, em via de regresso, pela solução total do debito.

"Art. 9. - 0 cancelamento da transcrição se fará pelo transcurso do prazo do contrato ou pela apresentação do certificado, acompanhado de quitação, ou prova bastante de extravio desse documento, acompanhada, então, de segunda via da quitação.

"Não tendo havido quitação voluntaria, juntar-se-á certidão de consignação em pagamento".

3. A inovação, anunciada pela mensagem presidencial, não passa, de certo modo, de uma renovação. Cuida-se, simplesmente, embóra modificadas, de restaurar as letras agricolas, que se tentou introduzir no paiz em 1889, como informou o Visconde de Ouro Preto em sua preciosa monografia - Credito movel pelo penhor e o bilhete de mercadorias, pag. 207, n. 14:

"A tentativa de introdução no paiz das letras agricolas, em 1889, por sua vez oferece valioso argumento em apoio desta interpretação dos atos do Governo Provisorio. No intuito de auxiliar a lavoura, ameaçada pela recente libertação dos escravos não só de perder safra abundante, por falta de numerario para assalariar trabalhadores, senão de restringir grandemente as suas explorações, o que redundaria em enorme prejuizo do Estado pela diminuição da receita, o autor deste escrito, então Ministro da Fazenda, contratou com varios bancos fornecerem dinheiro aos agricultores, a longo ou a curto prazo, mas sempre a juro modico, mediante hipoteca, penhor agricola, abertura de contas correntes e desconto de letras. Tais providencias tinham carater provisorio e se destinavam a acudir, de momento, a uma situação melindrosissima e obstar que se agravasse, enquanto o poder legislativo não votasse lei, organizando, sobre bases solidas, instituições de credito capazes de satisfazer permanentemente as necessidades da lavoura, lei cuja proposta 
se preparava com maxima solicitude. Obrigada a agir, sob pena de serem sacrificados interesses de ordem publica, não podia a administração fazer quanto pretendia, ou reputava util, mas o que lhe permitissem os elementos existentes. Não impunha porque não legislava; curava apenas de conseguir o que de melhor proviesse de convenções livremente estipuladas. Daí resultou que somente dois bancos anuiram á negociação de titulos representativos de generos de lavoura, em porção, qualidade e valor determinados, pagaveis á ordem, na mesma especie, ou a dinheiro, em tempo e lugar certos. Quer pela literal referencia que nas aludidas convenções se fez ao titulo italiano - ordine in derrate, como pela denominação dada aos que assim se tornaram descontaveis - letras agricolas, é fóra de duvida que seu objeto seriam produtos da lavoura, ou industrias conexas. Adotando, pois, os atos de 1890 denominação diversa e muito mais lata em sua significação - bilhetes pagaveis em mercadorias, inquestionavel é tambem que razoavelmente não se lhes póde atribuir a mesma inteligencia"

4. A despeito dos traços que um do outro diferenciavam, nota-se o ar de familia entre os dois titulos: o que se pretende criar - o certificado de penhor rural, e o regulado pelo art. 379 do decr. n. 370 , de 2 maio de 1890 - o bilhete de mercadorias. Este, dispunha ele, era valido e gozava de todas as garantias da letra de cambio. Devia conter a data; a qualidade das mercadorias consignadas; o nome e prenome da pessoa, a cuja ordem se devia fazer a consignação; a epoca em que esta havia de fazer-se; e o valor, como nas letras de cambio. Era titulo destinado a facilitar a permuta dos produtos agricolas por dinheiro ou outro valor. Era novo titulo de credito, permitindo a obtenção de dinheiro e de credito no presente, pelas colheitas futuras. Mas não teve aceitação. Não se teceu com ele a trama dos negocios. Não alimentou a circulação crediticia. Mas subsiste ainda na legislação em vigor. Considera-o o art. 1 paragr. unico, n. 2 , do decr. n. 5.746, de 9 de dezembro de 1929, obrigação 
liquida e certa, cuja falta de pagamento, no vencimento, carateriza o estado de falencia. Incluiu-o a lei $\mathrm{n}$. 160, de 31 de dezembro de 1935, entre os titulos suscetiveis de redesconto pela Carteira de Redescontos, estabelecida no Banco do Brasil, tendo a responsabilidade de duas firmas idoneas, uma das quais, obrigatoriamente, de agricultor. Não obstante, é como se tal titulo de credito não existisse. Improficuamente o plasmou a lei. Quanto a ele ficou ela sendo letra morta.

Cuida-se agora de criar outro titulo de credito, da mesma natureza, com a mesma garantia, um tanto diferente e com outro nome. Pegará? Terá, pelo menos, o sabor da novidadel.

5. Com identico proposito, e nos termos da lei de $\mathbf{1 8}$ de julho de 1898, modificada pela lei de 30 de abril le 1906 , instituiu-se, em França o warrant agricola. E' uma garantia conferida pelo agricultor a um credor, recaindo sobre produtos de sua exploração, que em sua posse permanecem ou ficam em poder de terceira pessoa, se assim se convencionar. A despeito das vantagens, que oferece, adverte $\mathrm{CH}$. Mazin, em Le Warrant Agricole, pag. 5, não se ha ele desenvolvido senão lentamente e em fraca medida, por varios motivos: "o espirito de rotina dos agricultores, pouco apressados no uso das novidades, sua aversão pelas formalidades e o temor de por estranhos no conhecimento de seus negocios. Mas a verdadeira razão parece estar no carater de incerteza e na fragilidade eventual dessa garantia particular. Permanecem em poder do devedor as cousas empenhadas; carece o credor de meios para thes preservar a conservação; os desvios são faceis e, posto reprimidos criminalmente, sempre possiveis" Salientou isso o tratadista, não sem objetar que, "para que o warrant agricola produza os serviços que dele se esperam e que o warrant comercial produz, é de mister que se estabeleça a semelhança entre os dois institutos, isto é, que os produtos warrantados sejam conservados, não em mãos do devedor, mas em armazens gerais, sendo confiados a 
sociedades cooperativas ou a sindicatos agricolas. Esta condição não se pode exigir, sem duvida, para o penhor pecuario, mas cabe em se tratando de colheitas".

Cá e lá, como se vê, o problema é o mesmo e mesmissimas as dificuldades a enfrentar para que o credito agricola tenha a facilidade, que se lhe pretende dar.

Admitindo a utilidade e, mesmo, a urgencia da warrantagem agricola, anotaram Georges Maurin \& Charles Broullhet, no Manuel Pratique de Crédit Agricole, pag. 87, viu-se o legislador na contigencia de escolher entre os dois meios: ou a criação de armazens gerais agriçolas ou a permissão para o proprio agricultor e devedor constituir-se empresario de armazem geral. Propendeu por este, adotando o sistema mais economico, neste enunciado contido: o agricultor pode contrair emprestimos sem se expôr á menor despesa de armazenagem e de transporte. Conferiu-lhe, neste sentido, superioridade ao comerciante e ao industrial. Qualquer destes tem, para a pratica de operação crediticia da mesma natureza, de consignar as suas mercadorias, em deposito, a armazem geral, que expedirá o titulo de credito, de que se cogita.

Serve isto de demonstrar, ao primeiro exame, a inteira semelhança do certificado de peuhor rural, do projeto, com o warrant agricola, da legislação francesa. São inumeras as suas afinidades. Como tal deve ser ele conceituado. Não teve receio o legislador francês de dar-lhe essa feição juridica, que emprestou, tambem, ao warrant hoteleiro, instituido pela lei de 8 de agosto de 1913, melhorado por leis posteriores. Ao hospedeiro é permitido contrair emprestimo, com garantia do mobiliario comercial, o material e os utensilios de serviço, mesmo se imobilizados por destino, conservando-os nos locais do hotel. 0 warrant respetivo é expedido pelo Tribunal do Comercio, como o agricola o é pelo oficial da Justiça de Paz.

6. Sendo o titulo, que se pretende criar, e outro objetivo não tem, em verdade, o anteprojeto governamental, um 
autentico warrant agricola, é de não esquecer que ele já se acha integrado no sistema legal brasileiro. Tanto, e tão torrencialmente, se legislou no periodo dos poderes discricionarios, ha pouco encerrado, que o proprio Governo se esqueceu de o haver instituido. Instituiu-o, realmente, o decr. n. 24.641, de 10 de julho de 1934, que criou o Banco Nacional de Credito Rural e estabeleu nórmas para o seu funcionamento, Instituiu-o nestes termos, agora relembrados:

\section{Capitulo III}

\section{Warrant agricola}

Art. 67 - Todo agricultor ou produtor rural, individual ou coletivamente e sem necessidade de outorga uxoria, poderá emitir warrants agricolas sobre frutos e produtos de sua exploração agricola ou pecuaria, de facil venda e cotados nos mercados, desde que possam se conservar, sem deterioração, por tempo demorado.

Art. 68 - 0 warrant agricola confere ao seu legitimo portador o direito de penhor sobre o objeto nele declarado, embora permaneça este na posse e sob a guarda do devedor, que responde como fiel depositario.

Paragrafo unico. - Participa da mesma natureza juridica excecional e da mesma proteção legal do penhor agricola, sendo-lhe extensivos tambem os preceitos reguladores da execução do warrant comercial, que por analogia the forrem aplicaveis.

Art. 69 - Além da garantia real sobre o objeto do warrant agricola, o portador tem a garantia pessoal, solidaria, dos endossantes, com todos os efeitos cambiais.

Art, 70 - 0 warrant agricola será tirado á ordem, no cartorio do Registro de Imoveis do municipio da situação da propriedade, pelo oficial, incumbido da transcrição dos direitos reais, e levará, além da data da emissão, sua designação particular.

Art. 71 - Para a emissão do warrant agricola o oficial do Registro de imoveis do municipio da situação da propriedade inscreverá num livro de talão, com as paginas numeradas, devidamente aberto, rubricado e encerrado pela autoridade judiciaria local: 
a) a natureza, quantidade e o valor do objeto;

b) o local em que se acha depositado;

c) o nome, nacionalidade, domicilio e profissão do emitente;

d) o nome da propriedade, do Estado, municipio, distrito ou freguezia, e da estação ferroviaria que a serve, bem como da respetiva via ferrea;

e) o numero da transcrição do dominio, livro e pagina em que foi feita;

f) os onus, impostos ou despesas por que respondam os produtos, tais como salarios de trabalhadores agricolas, quotas de arrendamentos, juros de hipotecas, premios de seguros, mencionando o nome do segurador, a importancia do seguro e seu prazo.

Paragrafo 1 - Ao negociar o warrant, serão averb́adas igualmente pela mesma fórma:

a) a importancia do emprestimo, taxa de juros e vencimento;

b) e quaisquer outras clausulas e condições estabelecidas entre as partes.

Paragrafo 2 - As declarações acima serão feitas tanto no tôco do livro, como na parte destacavel, que constituirá o warrant agricola; neste e naquele serão assinadas pelo emitente e rubricadas pelo oficial do registro, que atestará expressamente terem sido escritas com fidelidade.

Paragrafo 3 - Depois de anotadas no protocolo dos registros de imoveis, serão averbadas sucintamente no livro de transcrições de onus reais.

Paragrafo 4 - Se o emitente não souber assinar o nome, as declarações serão firmadas, a rogo, pelo oficial, na presença de duas testemunhas, que tambem assinarão, - que expressamente será mencionado no instrumento.

Paragrafo 5 - No verso do talão será passado recibo do warrant ou anotado o certificado do registro postal, caso seja remetido pelo correio.

Art. 72 - Não sendo proprietario ou usufrutuario da exploração, o agricultor deverá, antes de tirar o warrant, avisar por intermedio do oficial do registro de imoveis ao proprietario ou usufrutuario da quantia que pretende levantar e da natureza, quantidade e valor das mercadorias.

Paragrafo 1 - Este aviso será feito por carta registrada com recibo de volta e se ao fim de dez dias não fôr apresentada oposição, o warrant será extraido. 
Paragrapho 2 - Havendo oposição, será esta fundamentada; e se ainda assim insistir o agricultor na emissão do titulo, será o warrant extraido, fazendo-se nele constar a oposição e os seus fundamentos, assegurada a prelação que couber ao proprietario ou usufrutuario.

Art. 73 - Aquele que, para extrair um warrant agricola, fizer declarações falsas, afirmando a existencia, qualidade e quantidade de produtos e coușas em contrario á verdade ou que faça emitir warrant agricola sobre cousas e produtos já warrantados, sem permissão do primeiro warrant, ou que abandone, desvie, dissipe ou deteriore os produtos e objetos warrantados, prejudicando ao credor, será punido como estelionatario, incurso no grau maximo das penas do art. 338 da Consolidação das Leis Penais, aprovadas pelo decr. n. 22.213, de 14 de dezembro de 1932.

Art. 74 - Emitido o warrant agricola, os produtos e mercadorias de seu objeto não poderão sofrer embargo, penhora, sequestro ou qualquer outro embaraço que prejudique sua livre disposiçãa, salvo no caso de perda do titulo. Este será sujeito áquelas medidas processuais.

Art. 75 - Para levantar emprestimo com garantia de warrant agricola, o agente da atividade rural endossa-lo-á nos seguintes termos:

"Transfiro o presente warrant agricola á ordem de F. ........., residente em ........., profissão de .........., para garantia da importancia de.......... pagavel no dia de ......... aos juros de .....\% ao ano. Data e assinatura".

Paragrapho 1 - Os endossos seguintes deverão ser datados e assinados e enunciar o nome, profissão e domicilio dos endossatarios.

Paragrapho 2 - A cada endosso, o novo portador do warrant deverá, dentro de dez dias, comunicar, para averbação, a transferencia ao oficial que o extraiu, por carta registrada, ou verbalmente, contra recibo.

Art. 76 - Mesmo antes de vencido, o warrant agricola poderá ser resgatado, paga, por quem competir, a divida respetiva; e, nesse caso, os juros sobre o emprestimo só serão devidos até á data do resgate e mais quinze dias de abono.

Paragrafo unico - Se o credor recusar o resgate do warrant agricola, o emitente, para liberar o seu objeto, poderá consignar a importancia do emprestimo e dos 
juros, depositando-a no Banco Nacional de Credito Rural, ou organização dele dependente, em nome do credor e com indicação precisa do objetivo da consignação, cabendo ao Banco, sob as cominações de direito, dar imediato aviso ao credor, em carta registrada com recibo de volta.

Art. 77 - Resgatado o warrant agricola, o devedor fará averbar a liquidação nos livros mencionados no art. 71 e o oficial the dará declaração do cancelamento respetivo. Se fôr apenas amortizado, o respetivo montante será declarado no titulo e nos livros.

Art. 78 - Os oficiais do registro são obrigados a fornecer a qualquer interessado as certidões relativas aos warrants agricolas.

Art. 79 - Vencido e não pago o warrant agricola, ou não consignada sua importancia, o portador tem direito de mandar protesta-lo e, uma vez protestado, para a venda do objeto e cobrança da divida, proceder-se-á como no caso do warrant comercial, tomando o credor previamente posse do objeto do warrant, que lhe será entregue pelo devedor, sob as penas da lei.

Paragrafo 1 - A criterio do credor, o objeto poderá ser removido do local onde se ache ou aí permanecer sob sua guarda até liquidação da venda,

Paragrafo 2 - Esta terá lugar no cartorio do registro de imoveis, com a assistencia do respetivo oficial, que fará o recebimento do preço e immediatamente pagará ao credor, depositando, dentro de quarenta e oito horas, o remanescente, deduzidas todas as despesas, no Banco Nacional de Credito Rural, ou organização dele dependente e prevista neste decreto, a credito do Banco e por conta de quem de direito.

Art. 80 - o portador do warrant agricola que, den. tro de trinta dias do seu vencimento, não interpuzer o protesto por falta de pagamevto, ou que, dentro de trinta dias, contados da data do instrumento do protesto, não promover a venda das mercadorias, conservará tão somente ação contra o prixceiro endossador do warrant, alẻm do direito real sobre o seu objeto.

Art. 81 - Estão isentas de quasquer impostos, taxas e selos federais, estaduais e municipais, a emissão $\epsilon$ a circulação dos warrants agricolas, $t$ as custas, comissões e emolumentos de certidões, despachos, trans- 
crições, averbações, reconhecimentos de firmas, liquidaçōes e leilōes, a eles referentes, serão cobrados pela metade.

Paragrafo unico - De cada warrant agricola, pagará o emitente ao oficial do registro a importancia de cinco mil réis como custo do titulo e do trabalho do serventuario que o extrair.

Como do capitulo transcrito resulta, legem habemus.

Lei existe, longa e minuciosa, destinada a regular, incrementar e efetivar o credito rural. Criou o Banco Nacional de Credito Rural. Deu-lhe personalidade juridica, independente de registro e de qualquer outra formalidade. Atribuiu-lhe um patrimonio, constituido pelo capital de Rs. 100.000:000\$000, que o Governo lhe destinou, por adiantamento. Traçou-lhe as diretrizes. Dotou-o de uma Carteira de custeio rural, de outra Carteira do fomento e colonisação e de mais outra Carteira de credito fundiario. Disciplinou as Cedulas hipotecarias, os Bilhetes de penhor agricola e, por ultimo, os Warrants agricolas.

Lei de tal quilate, que se propôs atender á "necessidade da instituição do credito agrario, a rigor tecnico-profissional, sobre solidos principios da economia rural", atingivel somente "dentro da base sindical-cooperativa", pois "difficilmente um instituto bancario conseguirá realizar entre nós a distribuição do credito agrario senão á base da organização profissional dos agentes das atividades rurais"; lei de tal quilate se converteu em letra morta no mesmo dia em que foi publicada: 14 de julho de 1934 .

Embóra os titulos de credito, por ela criados, não houvessem ficado na dependencia do funcionamento, que jamais se verificou, do Banco Nacional de Credito Rural, tambem eles não chegaram a exercer a função, que lhes foi atribuida.

Ainda dessa vez os warrants agricolas não entraram na vida economica. Ficaram, como os bilhetes de mercadorias, a existir no texto legal. 
Não foi a legislação ditatorial da segunda republica, neste particular, mais eficiente que a da primeira republica.

Não lhe fez a mensagem presidencial de 25 de setembro de 1936 a minima alusão.

7. Necessidade não existe, pois, de lei nova sobre titulos de credito rural. Eles estão criados, tanto sob a forma de bilhetes de mercadorias, quanto sob a de warrants agricolas. Não ha carencia, antes abundancia de lei. $O$ que se reclama não é, pois, mais uma lẹi, mas que se dê vida aos textos que estão á espera dela, em consequencia de uma deliberada vontade de dar aos agricultores e aos criadores, de verdade, os recursos, de que tanto necessitam para o custeio dos seus serviços rurais. Que não se retardem, todavia, as providencias nesse sentido sob a invocação da inexistencia de lei especial, para isso elaborada.

8. Infere-se do exposto não se dever considerar como simples certificado de penhor rural ao titulo de credito em via de construção. Certificado é, sem duvida, o escrito em que alguma cousa se certifica ou se afirma. Não ha contestar. $\mathrm{Na}$ tecnica do direito brasileiro, porém, a transcrição, integral ou parcial, de inteiro teôr ou por extrato, e de fórma legal e autentica, do que está escrito em livros de notas ou de registro ou em cartorio se acha arquivado, de certidão sempre se chamou. Não se perca, a este proposito, o propicio ensinamento de Ferreira Borges, no vetusto, mas precioso, Dicionario Juridico-Comercial, pag. 91, de que certidão "é um ato pelo qual se dá testemunho dum fato. Tambem dizemos certidão o transsunto que faz um escrivão publico duns autos de teôr ou por extrato. Os negociantes vão introduzindo o nome certificado: entretanto parece inutil tendo nós a palavra certidão de bom cunho e uso". Diferentemente não se lê nos dicionarios da lingua. No de Noraes está que certidão é o "documento legal, em que autenticamente se certifica, se porta por fé alguma cousa, para a fazer verta onde cumprir: certidão de batismo, de objtu, etc". 
O titulo, que se trata de instituir, como warrant agricola, que vai ser, nem deve consistir, nem deve batisar-se como simples certificado.

9. No relatorio justificador do projeto de codigo comercial, escreveu INGLEZ DE Sodza ter preferido "á palavra peregrina warrant, usada na nossa legislação para designar a cautela anexa ao conhecimento do deposito de mercadorias entregues aos armazens gerais, a expressão cedula de penhor", que lhe pareceu mais propria, dando ao titulo integral a denominação conhecimento de deposito, usada pelo codigo português. $\mathrm{E}$ andou nisso acertadamente, pois, como refere Ferreira Borges, no Dicionario Juridico-Comercial, pag. 91, cedula é "um reconhecimento feito por escrito particular relativamente a alguma promessa, ou obrigação. Esta palavra vem do latim scheda ou schedula, que tem a mesma significação que bilhete, escrito".

Denominando cedula rural, simplesmente, ou cedula rural pignoraticia, ao novo titulo de credito, para melhor acentuar-lhe a natureza juridica, com inteira propriedade se lhe assentará a nomenclatura, individualizando-o inconfundivelmente.

10. Mas não basta resolver essa questão terminologica, que, em ultima analise, se resumiria numa questão de gosto, discutivel ao sabor de cada um. Não pode o titulo de credito consistir num certificado ou, mais propriamente, numa certidão em breve relatorio: como titulo formal, que ha de ser, de validade independente de sua causa em relação a terceiros, principalmente quanto aos que o negociarem, por via do endosso, ele deve ter, interiormente melhor estrutura, e, exteriormente, melhor aspecto, bem definido, parā poder entrar na circulação crediticia.

Năo sendo o official do registro imobiliario impedido de expedir uma ou mais certidões ou certificados do registro do penhor, não poucas duvidas hão de surgir acerca da validade ou, ao menos, da prioridade dos titulos, pela possi- 
bilidade da existencia de mais de uma via no giro economico, porta aberta para a fraude e, certamente, para o descredito do titulo agora em formação. De bôa cautela é, pois, prevenir essa hipotese e firmar certos principios, que garantam os direitos dos endossatarios e reendossantes desse novo instrumento de credito. Nem se compreende surja ele senão para ser negociado.

11. Com esse proposito, aceitando, em sua integridade, as sugestões contidas no anteprojeto aprovado pela douta Comissão de Agricultura, permite-se o relator deste parecer, examinando a questão pelo seu aspecto juridico, formular um substitutivo, em que se recolhem não apenas as observações já esboçadas, senão outras, justificadas por miudo na sucessão dos articulados. Não se trata de uma inovação, mas de um reajustamento juridico, mais de fórma do que de fundo.

$\mathrm{E}^{\prime}$ este o substitutivo:

\section{PROJETO}

Regula o penhor rural a cedula rural pignoraticia

\section{Justificação}

Os projetos de lei, preceitua o art. 49 da Constituição, serão apresentados com a respetiva ementa, enunciando, de fórma sucinta, o seu objetivo, e não poderão conter materia estranha ao seu enunciado.

Pela que se lhe deu, no projeto se trata "da reforma da legislação sobre o penhor rural"; mas não é bem disso que se cuida. Doutrinariamente pode-se considerar como rural tanto o penhor agricola quanto o pecuario, destacando-se este daquele para dar-lhe fisionomia propria; mas nenhuma lei existe sobre o penhor rural, de modo a poder ser reformada.

Regula o codigo civil, no seu livro II, titulo III, capitulo IX, o penhor, em geral, e, como modalidade dele, o agricola, que pode ter como objeto, tambem, os an mais do serviço ordinario do estabelecimento agricola. 
Instituindo o penhor rural, vại o projeto não só distinguir as suas duas especies, como, e primordialmente, criar o titulo de credito, representativo das cousas empenhadas, que se propõe denominar de - cedula rural pignoraticia.

A emenda substitutiva atende ao preceito constitucional còm mais justeza.

Art. 1. - Constitue-se o penhor rural pelo vinculo real, resultante do registro, por via do qual agricultores ou criadores sujeitam suas culturas ou animais ao cumprimento de obrigações, ficando como depositarios daquelas ou destes.

Paragrafo unico. - $O$ penhor rural compreende o penhor agricola e o penhor pecuario, confórme a natureza da cousa dada em garantia.

\section{Justificação}

$E^{\prime}$ essencial no penhor rural continuem as cousas empenhadas em poder do devedor por efeito da clausula constituti. Isso mesmo ficou expresso no art. 769 do codigo civil. Pareceu conveniente começar a lei por essa afirmação no projeto existente, num principio geral. que distancia o penhor rural do civil. Este se constitue pela tradição efetiva, que, em garantia do debito, ao credor, ou, a quem o represente, faz o devedor, ou alguem por ele, de um objeto movel, suscetivel de alienação.

Art. 2. - Contrata-se o penhor rural por escritura publica ou por escritura particular, transcrita no registro imobiliario da comarca em que estiverem situados os bens ou animais empenhados, para valimento contra terceiros.

Paragrafo 1. - A escritura particular pode ser feita e assinada ou somente assinada pelos contratantes, sendo subscrita por duas testemunhas.

- Paragrafo 2. - A escritura deve declarar:

I, os nomes, prenomes, estado, nacionalidade, profissão e domicilio dos contratantes;

II, o total da divida, ou sua estimação;

III, o prazo fixado para o pagamento;

IV, a taxa dos juros, se houver; 
$\mathrm{V}$, as cousas ou animais dados em garantia, com as suas especificações, de molde a individualiza-los;

VI, a denominação, confrontação e situação da propriedade agricola onde se encontrem as cousas ou animais empenhados, bem assim a data da escritura e notas de sua aquisição (1) e numero de sua transcrição imobiliaria;

VII, as demais estipulações usuais no contrato de mutuo.

\section{Justificação}

Não ha no tex́to nenhuma novidade. Tudo quanto nele se exara é correntio em direito. Preferiu-se, quanto á escritura particular, em vez de fazer referencia ao art. 135 do codigo civil, enunciar-lhe os dispositivos. $E$ estabeleceram-se os requisitos essenciais da escritura, publica ou particular.

Entre estes incluira o anteprojeto "a indicação do fim a que se destina a quantia emprestada". Omittiu-a o projeto. E nisso foi previdente. Aquela indicação, havida como requisito essencial do contrato, poderia servir para controversia em tôrno da bôa ou má aplicação da quantia mutuada, entravando quiçá a transmissibilidade do titulo.

Art. 3. - Pode ajustar-se o penhor rural em garantia de obrigação de terceiro, ficando as cousas ou animais em poder do proprietario e sob sua responsabilidade, não lhe sendo licito, como depositario, dispor deles, senão com o consentimento escrito do credor.

Paragrafo 1. - No caso de falecimento do devedor ou do terceiro penhorante, depositarios das cousas ou animais empenhados, pode o credor requerer ao juiz competente a imediata remoção do deposito para o poder do depositario, que nomear.

(1) Quando transitou o projeto pela Comissão de Finanças e Orçamento, o Deputado Horacio LAFER, relator do parecer, que aquela aprovou, propôs se intercalassem, depois de "aquisição", as palavras "ou arrendamento", que figuram no texto legal. Justificando a emenda, observou ser grande a quantidade de lavradores que arrendam terras e necessitam de financiamento para a sua exploração. 
Paragrafo 2. - Assiste ao credor ou endossatario da cedula rural pignoraticia direito para, sempre que lhe convier, verificar o estado das cousas ou animais dados em garantia, inspecionando-os onde se acharem, por si ou por interposta pessôa, e de solicitar a respeito informações escritas do devedor.

Paragrafo 3. - A provada resistencia ou recusa deste ou de quem ofereceu a garantia ao cumprimento do disposto no paragrafo anterior, importa, se ao credor convier, no vencimento da divida e sua imediata exigibilidade.

Paragrafo 4. - Em caso de abandono das cousas ou animais empenhados, pode o credor, autorizando-o o juiz competente, encarregar-se de os guardar, administrar e conservar.

\section{Justificação}

São os articulados preceitos contidos no anteprojeto e no projeto, com pequenas modificações de fórma. Esclareceu-se um tanto.

Art. 4. - Independe o penhor rural do consentimento do credor hipotecario mas não lhe prejudica o direito de prelação, nem restringe a extensão da hipoteca, ao ser executada.

Paragrafo 1. - Pode o devedor, independentemente de consentir o credor, constituir novo penhor rural, se o valor dos bens ou dos animais exceder ao da divida anterior (2).

Paragrafo 2. - Paga uma das dividas, subsiste a garantia para a outra, em sua totalidade.

Paragrafo 3. - As cousas e animais dados em penhor garantem ao credor, em privilegio especial, a importancia da divida, os juros, as despezas e as demais obrigações constantes da escritura.

(2) Sugeriu o Deputado Horacio LAFER, em seu parecer, na Comissão de Finanças e Orçamento, se ajuntassem ao paragrafo as expressões "ressalvadas para esta a prioridade de pagamento"

Aceita a proposição, ficou exarada no texto da lei. Pareceu ao seu autor aconselhavel, "para justa garantia do credor" esclarecer que o primeiro credor tem prioridade sobre os posteriores. 


\section{Justificação}

A hipoteca, nos termos do art. 811 do codigo civil, abrange todas as accessões, melhoramentos ou construções do imovel. Alcança os frutos pendentes e os animais empregados na exploração agricola da propried? de. Sempre se exigiu, por isso, o consentimento do credor para a constituição de penhor agricola, mas o art. 87 do decr. n. 24.641, de 10 de julho de 1934, expressamente aboliu essa exigencia.

Reproduziu-se o preceito no texto, esclarecendo-se outras situações.

Revogado se acha, pois, o art. 783 do codigo civil.

Art. 5. - Entre os direitos do credor pignoraticio compreendem-se ainda:

I, o valor do seguro dos animais empenhados, no caso de seu perecimento;

II, a indenização a que estiver sujeito o causador da perda ou deterioração dos bens ou animais empenhados, podendo exigir do devedor a satisfação do prejuizo sofrido por vicio ou defeito oculto;

III, o preço da desapropriação ou da requisição dos bens ou animais, em caso de utilidade ou necessidade publica.

\section{SEÇ̧̃̃̃o I.}

\section{Do penhor agricola}

Art. 6. - Podem ser objeto de penhor agricola:

I, colheitas pendentes ou em via de formação, quer resultem de previa cultura, quer de produção espontanea do sólo;

II, frutos armazenados, em ser, ou beneficiados e acondicionados para a venda;

III, madeira das matas, preparada para o córte, ou em tóras, ou já serrada e lavrada;

IV, lenha cortada ou carvão vegetal;

$\mathrm{V}$, maquinas e instrumentos agricolas. 
Art. 7. - 0 penhor agricola só se póde convencionar pelo prazo de um ano, ulteriormente prorrogavel por mais um; e, embóra vencido, subsiste a garantia enquanto subsistirem os bens que fazem objeto desta.

Paragrafo 1. - Sendo objeto de penhor agricola a colheita pendente ou em via de formação, abrange ele a colheita imediatamente seguinte, no caso de frustrar-se ou tornar-se insuficiente a dada em garantia (3).

(3) Sofreu o $\$ 1$ do art. 6 uma ampliação, proposta pelo Deputado HoRAcio LAFER, em seu parecer á Comissão de Finanças e Orçamento, de que é este pequeno capitulo:

"Um dos obices tambem serios que o penhor agricola sempre encontrou foi a eventual precariedade das garantias. Por exemplo, o calculo de uma safra pendente sujeita aos caprichos perigosos do tempo, o dificil contrôlo contra desvios, os abusos de deshonestos que, arrendando terras, desaparecem com a safra colhida para outros pontos, repetirão a façanha de receber os proventos sem pagar as dividas, $e$ muitos outros fatores representam elementos de temor para os que desejam aplicar capitais em emprestimos garantidos pelo penhor agricola. credor :

"O anteprojeto prevê, entre outras, as seguintes garantias para o penhor:

a) privilegio especial sobre as cousas ou animais dados em penhor;

b) garantia da colheita seguinte, se fôr insuficiente a dada em

c) prisão preventiva para os casos de inexistencia de cousas empenhadas.

"A primeira garantia é da propria essencia do instituto e, pela sua amplitude, constitue eficiente proteção para o credor. As outras duas, com a devida venia, nos parecem um pouco excessivas. Senão vejamos :

b) garantia da safra seguinte.

"Pelo art. 30 do substitutivo estabelece-se:

"Aplicam-se ao penhor rural, no que lhe fôrem pertinentes, as disposições sobre os direitos reais de garantia e os contratos de sua instituição".

"Portanto se a divida não fôr paga uma vez executado o contrato pignoraticio, todos os bens presentes e futuros do devedor responderão pela divida.

"Poder-se-á objetar que o devedor faltoso será livre de constituir novo penhor sobre a futura safra, passando a garantia para novo credor em detrimento do antigo. Evidentemente esta situação propicia até fraudes. Vejamos porém outro aspecto. Imagine-se um lavrador com sua safra prejudicada pelo máu tempo, inferior no seu valor á divida contraida e que deseja novamente plantar para conseguir o equilibrio das suas finanças. Se o antigo credor não the facilitar novos recursos, impossibilitado como estará de contrair outra divida pignoraticia, como irá ele prosseguir a sua vida de lavrador? 
Paragrafo 2. - Nesse caso, não chegando as partes a ajusta-lo, assiste ao credor o direito de, exibindo a prova do tanto quanto da colheita se lhe consignou ou se apurou ou de ter-se frustado no todo ou em parte, requerer ao juiz competente da situação da propriedade agricola que faça expedir mandado para a averbação de estender-se o penhor á colheita imediata.

Paragrafo 3. - Da decisão do juiz cabe o recurso de agravo de petição para a Cồrte de Apelação, interposto pelo credor ou pelo devedor.

\footnotetext{
"Parece-nos que a seguinte disposição conciliaria perfeitamente os interesses do credor e do devedor:

“\$ 1. Sendo objeto do penhor agricola a colheita pendente ou em via de formação abrange ele a colheita imediatamente seguinte no caso de frustrar-se ou ser insuficiente a dada em garantia. Quando, porém, não quizer ou não puder o credor, notificado com 15 dias de antecedencia, financiar a nova safra, fica o devedor com 0 direito de estabelecer com terceiro novo penhor, em quantia maxima equivalente ao primitivo contrato, considerando-se qualquer excesso apurado na colheita apenhado á liquidação da divida anterior".

Aceito o texto, que afinal veiu a ser o do $\S 1$ do art. 7 da lei n. 492 , de 30 de agosto de 1937, isso não aconteceu sem que tivesse sido impugnado. Apresentaram os Deputados Joaquim A. SAMpaio VIDAL e outros emenda supressiva dos paragrafos daquele artigo.

Manifestou-se a Comissão de Constituição e Justiça contrariamente a essa emenda, nos termos do parecer de seu presidente, 0 Deputado Waldemar Ferreira, de que é este trecho:

"Aceitas, pelo plenario, as emendas da Comissão de Finanças, que transformaram o texto do projeto no aqui reproduzido, parecem convenientemente salvaguardados os direitos das partes. Para darse extensão do penhor á safra imediatamente seguinte, é de mister, em primeiro lugar, estipulação expressa no contrato. Não existindo convenção, somente por via judicial pode ela dar-se. Nesse caso, além de caber ao credor o onus da prova da insuficiencia dos bens empenhados ou de ter-se frustrado a colheita, é indispensavel o despacho judicial, do qual cabe agravo de petição, interposto pelo credor, ou pelo proprio devedor. Estando o credor, por outro lado, obrigado a financiar a nova safra, sob pena de, em caso de recusa, poder o devedor da-la em penhor a terceiro, parece que a inovacão não deve ser desprezada. Fortalecerá, sem duvida, a garantia. Dará, talvez, ao penhor agricola melhor confiança, nos meios capitalistas e bancarios, que nẫo o veem com bons olhos. Tentou o projeto, destarte, dar-lhe maior valia.

"Não se aduziu, na emenda, argumento nenhum em seu prol. Nem se mostraram os males que do texto do projeto poderão advir. Bate-se a Sociedade Rural Brasileira contra o dispositivo projetado, exatamente nos termos da emenda em exame. Fala-se nela em. "verdadeira escravização do produtor aos compradores e intermedia-
} 
Paragrafo 4. - A prorrogação do prazo de vencimento da divida grantida por penhor agricola se efetua por simples escrito, assinado pelas partes e averbado á margem da transcrição respetiva.

\section{Justificação}

Projeto e anteprojeto reproduziram, levemente alterado, do art. 781 do codigo civil, o elenco das cousas suscetiveis de penhor agricola. Reaparecem elas no novo texto tambem com pequenas alterações.

Dois pontos de relevancia se salientam no art. 6 , despertando a atenção.

I. Por haver o art. 782 do codigo civil exarado o principio de só se poder convencionar o penhor agricola pelo prazo de um ano, por seis meses prorrogavel, generalizou-se o conceito de, findo o prazo ajustado e o da prorrogação, quando feita, desaparecer a garantia pignoraticia, não tendo sido a divida excutida.

Nessa corrente parece ter-se orientado o Governo, no anteprojeto; e tambem a Comissão de Agricultura, no projeto em exame, quando estabeleceram, aquele no art. 9 e este no art. 15, que "o cancelamento da transcrição se fará pelo transcurso do prazo do contrato". Deve operar-se o cancelamento, em tal caso, ope legis, por efeito, puro e simples, do transcurso do prazo de um ano.

Se, pois, o prazo do vencimento da divida fôr de

rios", mas não se demonstrou o asserto. Não teve o relator deste parecer, aceitando a proposta sugerida pelo anteprojeto governamental, outro proposito senão o de favorecer o credito agricola, evitando alguns dos motivos que o entorpecem. Embora se diga que o credito agricola não é função de particulares e sim do Estado, organizando bancos, com a sua responsabilidade, para fomentar a agricultura, unico meio de aumentar a riqueza nacional e do Brasil deixar de ser um paiz pobre, ninguem contesta que os bancos não deixarão sair o seu dinheiro sem garantia, pessoal ou real, do sè retorno ás suas arcas. Trata-se, no caso, de dar e fortalecer uma garantia real, que se exige e só entra em função, quando a pessoal inexiste. Não cogitou o projeto de outro aspecto do problema, que se lhe apresentou.

"Quanto á organização de bancos destinados ao fomento agricola, isso é materia de outro projeto, ora em discussão na Camara dos Deputados. Nele poderão ser acolhidas as sugestões de todos os interessados.

"O projeto, no ponto emendado, foi cauteloso e procurou assegurar, como lhe cumpria, os interesses em presença e adotou formula, que parece satisfatoria" (Diario do Poder Legislativo, n. 668, de 18 de julho de 1937, pag. 34.556 ). 
um ano e, no dia, não fôr paga, desaparece o penhor agricola, por considerar-se, de pleno direito, cancelada a respetiva transcrição.

Mas é da essencia do direito real de garantia a sua sobrevivencia ao prazo do vencimento da divida. Só depois dela vencida é que a garantia começa a operar, assegurando a efeitividade da ação a propor. Essa é a sua função precipua. Para evitar mal entendidos e para marcar-lhe esse papel preponderante no texto se declarou que, embóra vencido o prazo da divida, pois só então ela se torna exigivel, subsiste a garantia enquanto subsistirem os bens empenhados.

A clausula é salutar.

II. Projeto e anteprojeto propenderam por extender-se o penhor agricola, no caso de frustrar-se ou tornar-se insuficiente a colheita empenhada, á imediatamente seguinte. Aceitou-se a inovação. Mas, aceitando-a, julgou-se de mister dar ao credor, em falta de ajuste, o direito de, exibindo a prova do tanto quanto da colheita se lhe consignou ou se apurou ou de ter-se frustrado no todo ou em parte, requerer ao juiz competente da situação da propriedade agricola que faça expedir mandado para a averbação de extender-se o penhor á colheita imediatamente seguinte, dando-se o recurso de agravo de petição do despacho judicial.

Nem de outro modo podia ser.

Qual seria o criterio para haver como insuficiente ou frustrada a colheita empenhada?

Adotou-se forma judicial para segurança dos direitos dos contratantes, tanto do credor, quanto do devedor.

III. No concernente á prorrogação convencional do prazo da divida, contentou-se o substitutivo com o simples escrito assinado pelos contratantes. Alargou-se para um ano, no entanto, o prazo de seis mezes ao qual permitia o codigo civil a prorrogação. Nada impede que de um ano seja. E se se tratar de produto agricola de facil e duradoura conservação, depois da colheita?

Art. 8. - Pode-se estipular, na escritura de penhor agricola, que os frutos, tanto que colhidos e convenientemente preparados para o transporte, sejam remetidos pelo devedor ao credor, ou para que se torne simples depositario deles, 
ou para que os venda, por conta e segundo as instruções do devedor ou os usos e costumes da praça, marcando-se os prazos e quantidades das remessas.

Paragrafo unico. - Nesse caso, o credor, sujeito ás obrigações e investido dos direitos de comissario, prestará contas ao devedor, de cada venda, que fôr realizando (4).

\section{Justificação}

Tratando-se de estabelecer e desenvolver o credito rural não se deve abandonar o que a pratica tem demonstrado. Quasi sempre o financiador agricola fornece o dinheiro com o proposito de receber os frutos e vendelos. Assim se formou e desenvolveu-se o comercio comissario de café. Assim se procede no do algodão, no do assucar e no de outros produtos.

Não raro, por outro lado, é que o penhor agricola funcione como pacto adjeto do contrato de abertura de credito em conta corrente.

Em tais condições, fique expresso em lei poderem as partes estipular no sentido exposto no articulado em apreço.

(4) Pleitearam os Deputados Joaquim A. SAmpaio Vidal e outros, por emenda, a supressão do art. 8 e seu paragrafo. Emitindo parecer, na Comissão de Constituição e Justiça, sobre ela, o Deputado Waldemar Ferreira assim se manifestou:

"Não se contem nesse dispositivo inovação alguma, que possa ofender os melindres ou os interesses do devedor. Acolheu-se nele pratica de ha muito observada e com sucesso continuada no comercio, principalmente no comissario de café e frequentissimo na praca de Santos. Dá-se ali o financiamento das lavouras cafeeiras com - contrato de penhor agricola, assumindo o lavrador a obrigação de remeter o seu café ao comissario, em partidas e epocas ajustadas no contrato. $\mathrm{O}$ projeto não fez mais do que legalizar essa pratica, permitindo-a expressamente. Veiu da observação da vida comercial o dispositivo. A norma existe já, mas por força dos usos e costumes, que alcançam, dessarte, a sua ultima etapa, cristalizandose no texto legislativo".

E concluiu:

"O texto impugnado merece ser mantido no projeto. Consigna uma faculdade, mas não é redundante, nem dispensavel. Não o adote, nos seus contratos, quem dele não carecer; mas deixe-se a cada um a faculdade de resolver os seus negocios pelo modo já constante da velha pratica. A boa lei é a que por via dela se fórma" (Diario do Poder Legislativo, n. 668, de 18 de julho de 1937, pag. 34.558). 
Art. 9. - Não vale o contrato de penhor agricola celebrado pelo locatario, arrendatario, colono ou qualquer prestador de serviços, sem o consentimento expresso do proprietario agricola, dado previamente ou no ato da constituição do penhor.

Paragrafo unico. - Na parceria rural, o penhor somente pode ajustar-se com o consentimento do outro parceiro e recai somente sobre os animais do devedor, salvo estipulação diversa (5).

\section{SEcçÃo II \\ Do penhor pecuario}

Art. 10. - Podem ser objeto do penhor pecuario os animais que se criam pascendo para a industria pastoril, agricola ou de laticinios, em qualquer de suas modalidades, ou de que sejam eles simples accessorios ou pertences de sua exploração.

Paragrafo unico. - Deve a escritura, sob pena de nulidade, designar os animais com a maior precisão, indicando o lugar onde se encontrem e o destino, que têm, mencionando de cada um a especie, denominação comum ou cientifica, raça, grau de mestiçagem, marca, sinal, nome, se tiver, e todos os carateristicos por que se identifique.

Art. 11 - E' o penhor pecuario ajustavel independentemente do penhor agricola; nada, porém, se opõe a que se celebre conjuntamente com ele, para a garantia da mesma. divida, ficando, neste caso, subordinado á disciplina deste, no qual se integra.

(5) Omitiram-se por descuido, na redação do texto, as expressões "a parte dos frutos" da clausula final, que deveria ter sido esta: "recái somente sobre a parte dos frutos ou animaes do devedor, salvo estipulação diversa". Era, com outra redação, o que estava no art. 6 do projeto. Como está, o articulado deveria, em rigor, figurar na seção seguinte, atinente ao penhor pecuario. Foi um lapso, que a jurisprudencia poderá corrigir, decidindo por analogia, quanto ao. penhor agricola. 
Paragrafo unico. - Como o agricola, o penhor pecuario independe de outorga uxoria.

\section{Justificação}

Seguindo, de perto, o codigo civil, que não distingue, propriamente, o penhor pecuario do agricola, anteprojeto e projeto entre as cousas, que podem ser objetodeste, incluiram "os animais do serviço ordinario do estabelecimento agricola". Desde que se passou a distinguir um do outro, estes foram suprimidos da enumeração do art. 5. Mas como pode acontecer que os animais devam tambem ser dados em garantia, Iançou-se o preceito que ro texto se lê.

Art. 12. - Não póde o devedor vender o gado, nem qualquer dos animais empenhados, sem prévio consentimento escrito do credor.

Paragrafo 1. - Quando o devedor pretenda vende-los ou, por negligente, ameace prejudicar ao credor, pode este requerer se depositem os animais sob a guarda de terceiro ou exigir que incontinenti se lhe pague a divida.

Paragrafo 2. - Os animais da mesma especie comprados para substituir os mortos, ficam subrogados no penhor

Paragrafo 3. - Esta substituição presume-se, mas não vale contra terceiros se não constar de menção adicional ao respetivo contrato.

Art. 13. - O penhor pecuario não admite prazo maior de dois anos, mas pode ser prorrogado por igual periodo, averbando-se a prorrogação na transcrição respetiva.

Paragrafo unico. - Vencida a prorrogação, deve o penhor ser reconstituido, se não executado.

\section{CAPITULO II}

\section{Da cedula rural pignoraticia}

Art. 14. - A escritura, publica ou particular, de penhor rural deve ser apresentada ao oficial do registro imo- 
biliario da circunscrição ou comarca, em que estiver situada a propriedade agricola em que se encontrem os bens ou animais dados em garantia, afim de ser transcrito, no livro e pela fórma por que se transcreve o penhor agricola.

Paragrafo unico. - Quando contraido por escritura particular, dela se tiram tantas vias quantas julgadas convenientes, de modo a ficar uma, com as firmas reconhecidas, arquivada no cartorio do registro imobiliario.

\section{Justificação}

Se, no registro imobiliario, determinou o art. 5, b), n. XII, da lei n. 4.827, de 1924, se efetue a transcrição do contrato de penhor agricola - no registro de titulos e documentos manda transcrever-se, como dispõe o art. 4, a) n. IV, o contrato, por instrumento particular, de penhor de animais, não compreendido nas disposições do art. 781, n. V, do codigo civil, que trata do penhor agricola.

Traçou o regulamento, aprovado pelo decr. n. ... 18.542, de 24 de dezembro de 1928, a fórma de transcrição do contrato de penhor agricola, ainda quando abrangendo os animais do serviço ordinario do estabelecimento agricola.

Pretende-se, como é obvio, considerando o penhor agricola e o penhor pecuario especies do penhor rural, cada um como instituto autonomo, submete-los, no entanto, ao mesmo registro, com aplicação dos dispositivos atinentes, atualmente, ao penhor agricola.

Tendo-se, entretanto, alargado o conceito do penhor pecuario, no registro imobiliario se dará a transcrição apenas do constituido em garantia de divida agricola ou, melhor, de divida rural. O penhor de animais sujeitos a registro especial, neste é que deve ser devidamente transcrito para valer contra terceiros.

Art. 15. - Feita a transcrição da escritura de penhor rural, em qualquer de suas modalidades, pode o oficial do registro imobiliario, se o credor lho solicitar, expedir em seu favor, averbando-o á margem da respetiva transcrição, e 
entregar-lhe, mediante recibo, uma cedula rural pignoraticia, destacando-a, depois de preenchida e por ambos assinada, do livro proprio.

Paragrafo 1. - Haverá, em cada cartorio de registro imobiliario, um livro talão, de folhas duplas e de igual conteudo, do modelo anexo, numerado e rubricado pela autoridade judiciaria competente, contendo cada uma:

I, a designencia do Estado, comarca, municipio, distrito ou circunscrição;

II, o numero e data da emissão;

III, os nomes do devedor e do credor;

IV, a importancia da divida, seus juros e data do vencimento;

V, a denominação e individuação da propriedade agricola em que se acham os bens ou animais empenhados, indicando a data e tabelião em que se passou a escritura de acquisição daquela ou o titulo por se se operou, numero da transcrição respetiva, data, livro e pagina em que esta se ef etuou;

VI, a identificação e a quantidade dos bens e dos animais empenhados;

VLil, a data e o numero da transcrição do penhor rural;

VIII, as assinaturas, de proprio punho, nas duas folhas, do oficial e do credor.

Paragrafo 2. - Se o credor pignoraticio não souber ou não puder assinar, será o titulo assinado por procurador, com poderes especiais, ficando a procuração, por instrumento publico, arquivada em cartorio.

\section{Justificação}

Deve a cedula rural pignoraticia expedir-se por conveniencia e mediante solicitação do credor. Só este está em condições de julgar da sua utilidade, pois que só ele poderá desconta-la, introduzindo-a, por via do endosso, na circulação economica, como titulo de credito, que é. Dispensa o substitutivo a interferencia do devedor na expedição do titulo. Mas exige que se o penhor 
rural tiver sido celebrado por escritura particular no cartorio fique arquivada uma de suas vias, para a soluȩão de duvidas de futuro oriundas. Teve o relator en mente a repugnancia universal do agricultor pela assinatura de documentos. Respeitou-a. Respeitando-a, procurou a solução mais adequada, a que no texto consignou.

Prevendo a hipotese de não saber ou de não poder assinar a cedula o credor, exigiu a sua representação por procurador com poderes especiais e a procuração lavrada por tabelião.

Art. 16. - A cedula rural pignoraticia é transferivel, successivamente, por endosso em preto, em que á ordem de pagamento se acrescente o nome ou firma do endossatario, seu domicilio, a data e a assinatura do endossante. O primeiro endossante só pode ser o credor pignoraticio.

Paragrafo unico. - 0 endosso é puro e simples, reputando-se não escrita qualquer clausula condicional ou restritiva; e investe o endossatario nos direitos do endossante contra os sinatarios anteriores, solidariamente, e contra o devedor pignoraticio.

Paragrafo 2. - 0 endosso parcial é nulo.

Paragrafo 3. - 0 endosso cancelado é inexistente, mas habil para justificar a serie das transmissões do titulo.

Paragrafo 4. - 0 endossante responde pela legitimidade da cedula rural pignoraticia e da existencia das cousas ou animais empenhados.

Paragrafo 5. - $\mathrm{O}$ endosso pode ser garantido por aval.

Art. 17 - Expedindo a cedula rural pignoraticia, dá o oficial, imediatamente, por carta, mediante recibo, aviso ao credor pignoraticio; e os endossatarios devem apresentarlha para que, averbando o endosso á margem da transcrição, nela o anote.

Paragrafo unico. - Ao averbar o endosso, o oficial averbará os anteriores ainda não anotados.

Art. 18. - Emitida a cedula rural pignoraticia, passa a escritura de penhor a fazer parte dela, de modo que os di- 
reitos do credor se exercem pelo endossatario, em cujo poder se encontre e invalido é o pagamento porventura efetuado pelo devedor sem que o titulo lhe seja restituido ou sem que nele registre o endossatario o pagamento parcial realizado, dando recibo em separado, para o mesmo efeito.

Paragrafo unico. - Não podem os bens, nem os animais empenhados ser objeto de penhora, arresto, sequestro ou outra medida judicial, desde que expedida a cedula rural pignoraticia, obrigado o devedor, sob pena de responder pelos prejuizos resultantes, a denunciar aos oficiais incumbidos da diligencia, para que a não efetuem, ou ao juiz da causa, a existencia do titulo, juntando o aviso recebido ao tempo de sua expedição (6).

Art. 19. - E' a cedula rural pignoraticia resgatavel a qualquer tempo, desde que se efetue o pagamento de sua importancia, mais os juros devidos até o dia da liquidação; e, em caso de recusa por parte do endossatario constante do registro, pode o devedor fazer a consignação judicial da importancia total da divida, capital e juros até ao dia do deposito, citado aquele e notificado o oficial do registro imobiliario competente para o cancelamento da transcrição e anotação no verso da folha do talão, arquivando a respetiva contra fé, de que constará o teôr do termo de deposito.

(6) Transformou-se este paragrafo unico em segundo, por proposta do Deputado Horacio Lafer, no seu parecer á Commissão de Finanças e Orçamento, nestes termos consignado:

"Os atuais financiamentos da lavoura, mesmo com o penhor agricola, são feitos em varias prestações, segundo as necessidades do custeio. Assim, se a cedula pignoratica fôr extraida pelo total da divida, acontecerá que o credor, não tendo ainda entregue toda a quantia, passará a devedor.

"Justifica-se, pois, a seguinte emenda:

"Art. - Quando o emprestimo estabelecido na escritura do penhor rural fôr entregue em parcelas periodicas, ao devedor será permitida a expedição de varias cedulas pignoraticias, conforme as quantias e prazos acordados, devendo, porem, constar nas respetivas cedulas o numero da transcrição da escritura e quantia total do penhor contratado"

Este artigo veiu a ser o primeiro paragrafo do art. 18. 
Paragrafo unico. - A consignação judicial libera os bens ou animais empenhados, subrogando-se o vinculo real pignoraticio na quantia depositada.

Art. 20. - Tentando o devedor ou o terceiro, como depositario legal, desviar, no todo ou em parte, ou vender, sem consentimento do credor pignoraticio ou do endossatario da cedula rural pignoraticia os bens ou animais empenhados, tem este direito para requerer ao juiz que os remova para o poder do depositario publico, se houver, ou particular, que nomear, correndo todas as custas e despezas por conta do devedor.

Paragrafo unico. - Desviados ou vendidos, com infração do neste artigo disposto, pode o juiz determinar-lhes o sequestro, cuja concessão importa no vencimento da divida e sua exigibilidade.

Art. 21. - Cancela-se a transcrição do penhor rural:

I, a requerimento do credor e do devedor, conjuntamente, se não expedida a cedula rural pignoraticia;

II, pela apresentação da cedula rural pignoraticia, caso em que o oficial, depois de lançar, no verso da primeira via, no livro talão, o cancelamento, a devolverá ao apresentante com anotação identica;

III, pela consignação judicial da importancia total da divida, capital e juros, até ao dia do deposito;

IV, por sentença judicial.

\section{Justificação}

I. Tal qual no substitutivo se contem, a cedula rural pignoraticia se apresenta como uma cambial rural, de livre circulação no mundo bancario e mercantil. Como titulo de credito, representa os bens ou animais empenhados, por efeito de sua emissão declarado impenhoraveis e insusceptiveis de qualquer medida preventiva judicial, que a desguarneça de sua garantia real.

II. Circulando por via do endosso, foi este convenientemente regulado, de modo a permitir o exercicio dos direitos do credor pignoraticio, em que o endossata- 
rio se investe, sem prejudicar aos do devedor. Em beneficio deste, regulou-se a consignação judicial da divida, com efeito liberatorio dos bens ou animais empenhados, operando-se na importancia depositada a subrogação do vinculo real pignoraticio.

III. Tratou-se, por ultimo, dos casos de cancelamento da transcrição do penhor rural no registro imobiliario.

\section{Capitulo III}

\section{Da excussão pignoraticia}

Art. 22. - Vencida e não paga a cedula rural pignoraticia, o seu portador, como endossatario, deve apresenta-la ao devedor, nos tres dias seguintes, afim de ser resgatada.

Paragrafo 1. - A apresentação pode ser feita por via do oficial de protestos, pessoalmente ao devedor, ou por carta, mediante recibo, em que lhe dê o aviso de achar-se em seu cartorio, afim de ser resgatada, sob pena de protesto.

Paragrafo 2. - Findo o prazo de tres dias, sem pagamento, o oficial tira, nos tres dias seguintes, o instrumento do protesto com as formalidades do protesto cambial, dando dele aviso a todos os endossantes, naquele prazo, por carta registrada, na impossibilidade ou dificuldade de fazer a notificação pessoal.

Paragrafo 3. - Se o devedor pignoraticio, por não encontrado, tiver de ser citado por edital, neste não se mencionarão os nomes dos endossantes.

Paragrafo 4. - A falta de interposição do protesto desonera os endossantes de qualquer responsabilidade pelo pagamento da cedula rural pignoraticia.

Art. 28 - Tirado o protesto, o devedor é citado para, no prázo de quarenta e duas horas, que correrá em cartorio, a contar do momento da entrega, neste, da fé de citaçâo, efetuar o pagamento ou depositar, em juizo, as cousas ou animais empenhados. 
Paragrafo 1. - A petição inicial é instruida com a cedula rural pignoraticia e instrumento de protesto.

Paragrafo 2. - Quando o penhor tiver sido dado por terceiro, será este o citado para efetuar o deposito, em prazo igual se, naquele, não tiver sido o pagamento efetuado.

Paragrafo 3. - Não realizado o deposito, pode o credor requerer:

I, o sequestro dos bens ou animais empenhados, dandose-lhes depositario judicial;

II, não encontrados os bens ou animais, a prisão preventiva do devedor ou do terceiro, que deu a garantia e ficou como depositario legal (7).

Paragrafo 4. - Efetuada a prisão preventiva o juiz determina ao escrivão tire, em cinco dias, traslado dos autos e imediatamente o encaminhe ao juiz criminal competente,

(7) Suprimiu-se o n. II do $\S 3$, passando este, na lei, a ter esta redação:

“§ 3. Não realizado o deposito, pode o credor requerer o sequestro dos bens ou animais empenhados, dando-se-lhes depositario judicial".

Resultou isso de sugestão do Deputado Horacro LAFER, no seu parecer á Comissão de Finanças e Orçamento, deste teôr:

"Prisão preventiva:

"Não realizado o deposito pode o credor requerer:

"II, não encontrados os bens ou animais, a prisão preventiva do devedor".

"Esta disposição teria o seguinte resultado: sem culpa do devedor impossibilitado de depositar uma quantidade contratada de produtos que uma safra infeliz não proporcionou, a sua prisão preventiva por dividas não pagas.

"O que se deve punir é o desvio criminoso por parte dos deshonestos que, felizmente, constituem casos isolados e raros.

"Ora, o codigo penal, art. 338, dispõe:

“Julgar-se-á crime de estelionato alheiar, ou desviar os objetos dados em penhor agricola, sem consentimento do credor, ou por qualquer modo defraudar a garantia pignoraticia.

"Penas de prisão celular por um a quatro anos e multa de 5 a $20 \%$ do valor do objeto sobre que recair o crime.

“A pena, portanto, contra os deshonestos já é severa. Parecenos, portanto, que o n. II do art. $23, \S 3$, deve ser suprimido". 
se tambem ele não tiver jurisdição criminal e competencia para o processo, caso em que o instaurará (8).

Paragrafo 5. - Recebido e autuado o traslado no juizo criminal, o promotor publico of erece a denuncia para $o$ devido processo, na fórma da lei.

Paragrafo 6. - 0 credor pignoraticio ou o endossatario pode apresentar queixa, antes de dada a denuncia, e o promotor publico adita-la e promover as diligencias, que julgar necesarias, sem prejuizo das de iniciativa do queixoso.

Paragrafo 7. - Se o querelante não der andamento ao processo, incumbe ao promotor publico dar-lhe movimento.

Art. 24. - 0 credor pignoraticio, quando não expedida a cedula rural, juntando uma das vias da escritura particular ou certidão da publica, pode praticar as diligencias constantes do art. 23 e paragrafos, independentemente de protesto.

Art. 25. - Feito o deposito ou o sequestro, tem o devedor o prazo de seis dias para defender-se por via de embargos.

Paragrafo 1. - Sendo estes irrelevantes, pode o juiz despreza-los, condenando o devedor ao pagamento pedido, despezas judiciais e custas.

Paragrafo 2. - Sendo relevantes, pode recebe-los e mandar contestar, dando ao processo o curso sumario.

Paragrafo 3. - Nas hipoteses dos paragrafos anteriores, manda o juiz expedir, incontinenti, alvará para a venda dos bens ou animais empenhados, insuspensivel sob qualquer pretexto ou por qualquer recurso, respondendo ele e o escrivão, solidariamente, pelo retardamento.

(8) Deu-se, no caso, inadvertencia, muito comum, de resto, nos trabalhos legislativos. Suprimido o n. II do paragrafo anterior, que permitia a decretação da prisão preventiva, devia ter-se adaptado o $\S 4$ ao sentido da emenda, que o alterara ou, o que teria sido mais acertado, suprimido os paragrafos subsequentes. Assim, infelizmente, não aconteceu. Mas não ha como deixar de considerar inuteis os paragrafos quatro a sete, em que se coordenou a formula processual, especialmente estabelecida para a hipotese... 
Paragrafo 4. - Provado, documentalmente, o pagamento, o juiz, julgando extinta a ação, manda cancelar a transcrição do penhor, condenando o autor nas despezas judiciais e custas.

Art. 26. - Se tiver sido ajustada a venda amigavel, esta se fará nos termos convencionados e, sempre que possivel, por corretor oficial.

Paragrafo unico. - A venda judicial se realizará em leilão publico, por leiloeiro, ou, onde não existir, pelo porteiro dos auditorios ou quem suas vezes fizer.

Art. 27. - No caso de venda amigavel, se o resultado se mostrar insuficiente para o pagamento integral da divida, assiste ao credor o direito de prosseguir na excussão, penhorando tantos bens do devedor, quantos bastarem, seguindo-se como na ação executiva.

Paragrafo 1. - Procede-se, nesse caso ao cancelamento da transcrição, por mandado judicial.

Paragrafo 2. - Se a excussão tiver sido de cedula rural pignoraticia, o endossatario prestará, em juizo, contas da rexecução, citando a todos os coobrigados para a impugnarem, se quizerem, por embargos, que serão processados como na ação de prestação de contas.

Art. 28. - No caso de venda judicial, o preço será depositado em juizo e levantado pelo exequente, depois de efetuado o pagamento,

I, das custas e despezas judiciais;

II,dos impostos devidos.

Paragrafo 1. - O saldo, se houver, se restitue ao credor.

Paragrafo 2. - Pela importancia que faltar para o pagamento integral da divida, seus juros, despezas e custas, tem o endossatario ação executiva contra o devedor pignoraticio e os endossantes, avalistas ou coobrigados, todos solidariamente responsaveis: a ação pode ser proposta contra todos conjuntamente ou contra cada um ou alguns separadamente, como lhe convier. 
Paragrafo 3. - Cada endossatario tem direito de rehaver do seu endossante, por ação executiva, a importancia, que pagar.

Paragrafo 4. - Se os bens, em leilão publico, não encontrarem licitantes, é permitido ao credor requerer-lhes a adjudicação, pela avaliação constante do contrato ou pela que, em juizo, se fizer (9).

Art. 29. - Perde o direito e ação contra os coobrigados no pagamento da cedula rural pignoraticia, por efeito de endosso ou de aval, o endossatario ultimo, se não praticar as diligencias do art. 22 e seguintes dentro em quinze dias depois de tirado o instrumento do protesto.

Art. 30. - Não se suspende a excussão do penhor pela morte ou pela falencia do devedor, prosseguindo contra os herdeiros e o sindico ou liquidatario.

\section{Justificação}

I. O que mais tem contribuido para a prevenção, ainda reinante, contra o penhor agora de rural chamado, é a inercia do credor e a quasi impossibilidade, em que ele se encontra, de agir eficientemente contra o devedor.

Inutil é, realmente, iniciar a excussão do penhor, quando desviada e vendida a cousa empenhada. Como alcança-la, no exercicio do direito de sequela, afim de sequestra-la? Se tiver sido despachada por via ferrea, maritima ou aerea, a impossibilidade se torna maior, em face da impenhorabilidade das mercadorias despachadas, depois de expedido o conhecimento do respetivo transporte.

Emittida, porém, a cedula rural pignoraticia, esse estado de inercia não pode e não deve subsistir. Daí a serie de diligencias, consignadas no substitutivo, muitas reproduzidas do projeto, tendentes a tornar efetiva a

(9) Acresceu-se ao texto, na redação final, a clausula: "prosseguindo na ação pelo saldo crediticio", com o intuito evidente de esclarecer. 
excussão do penhor não só no civel, quanto no crime, verificado o desvio dos bens ou animais empenhados.

II. Não haverá, segundo o preceito do art. 113, n. 30 , da Constituição, prisão por dividas, multas ou custas. Ainda está indecisa a jurisprudencia no aplicar esse dispositivo constitucional. Com fundamento nele tem sido negada a prisão dos depositarios infieis. Não se justifica essa interpretação. Quem, como depositario, não restitue a coisa depositada, pratica o crime de apropriação indebita, ou outro que mais se ajuste ao caso concreto. Não deixa de pagar uma divida apenas.

No intuito de evitar essa controversia, prefere o substitutivo que, não entregue a cousa empenhada, pelo depositario, no prazo legal, e verificada a impossibilidade de sequestra-la, o juiz lhe decrete a prisão preventiva, tomando-se, imediatamente, as medidas indispensaveis para a instauração do processo criminal, por ação publica.

Esta é; sem duvida, inovação, que produzirá os resultados mais salutares em prol do credito rural, fortalecendo-o e tornando-o eficiente.

III. Disciplinou-se a materia processual, com simplicidade de formulas e o proposito de emprestar-lhe agilidade de movimento.

\section{Capitulo IV}

\section{Das disposições gerais}

Art. 31. - Aplicam-se ao penhor rural, no que lhe fôrem pertinentes, as disposições sobre os direitos reais de garantia e os contratos de sua instituição.

Art. 32. - Ficam isentos de quaisquer tributos federais, impostos ou taxas, o contrato de penhor rural e sua transcrição, bem assim a expedição da cedula rural pignoraticia e os atos nela lançados, o endosso, o aval e recibos (10).

(10) Aconselhando medidas tendentes a favorecer aos interessados, assim se exprimiu, em seu parecer, o Deputado Horacio LAFER:

"As elevadas despesas que o lavrador era obrigado a fazer para contrair o emprestimo com o penhor em muito tambem concorrer- 
Art. 33. - Pela transcrição do penhor rural as custas do oficial do registro imobiliario são as do regimento em vigor, em hipotese alguma excedente de 50\$000; pela expedição da cedula rural pignoraticia de 10\$000; e pela averbação dos endossos, $5 \$ 000$, cada vez, cabendo-lhe importancia igual pelo cancelamento da transcrição.

Paragrafo unico. - $O$ oficial não pode, sob pena de responsabilidade, recusar ou demorar a transcrição e a expedição da cedula rural pignoraticia.

ram para a falta de expansão desta fórma de financiamento. 0 substitutivo, no art. 32, é feliz com as isencões que concede. Entre elas foi omitida a das estampilhas.

"Propomos, pois, o seguinte:

"Art. 32. Ficam isentos de quaisquer tributos federais, impostos, taxas e estampilhas, o contrato de penhor rural e sua transcrição, bem assim a expedição da cedula rural pignoraticia e os atos nela lançados, o endosso, o aval e recibos".

Esse artigo, entretanto, foi suprimido, na redação final do projeto. Ao ser aquela submetida a votos, em sessão de 14 de agosto de 1937, aprovou-a a Camara dos Deputados, sem prejuizo de requerimento do Deputado Carlos Luz, no sentido de ser dele destacado o art. 32.

Foi o destaque concedido (Diario do Poder Legislativo, n. 692 , de 15 de agosto de 1937, pag. 38.723) afim de constituir aquele artigo projeto separado a ser remetido, depois da discussão especial, ao Senado Federal, pois a materia nele contida tinha e tem, efetivamente, de ser submetida ao exame daquele orgão, como colaborador na elaboração das leis enumeradas no art. $91, \mathrm{n}$. I, da Constituição, entre as quais se incluem as sobre "tributos e tarifas". Tratando o art. 32 de isenção de tributos, era indispensavel a colaboração do Senado. Porque, entretanto, o Regimento Comum á Camara dos Deputados e ao Senado Federal prescreve, no art. 12, que "os projetos de leis, aprovados pela Camara, que contenham dispositivos sobre materia de colaboração do Senado, serão submetidos á aprovação deste somente na parte referente a tais dispositivos" - teve o destaque por intuito atender a esse preceito, fundado no $\S 4$ do art. 261 do Regimento Interno da Camara dos Deputados, mercê do qual, ao ser votada a redação final de projeto, qualquer parte dele pode ser destacada para constituir projeto separado, sofrendo discussão especial, que poderá, todavia, ser dispensada pelo plenario.

$\mathrm{E}$ isso, no caso, aconteceu.

Eis porque, apesar de aprovado o projeto, na integra, em terceira e ultima discussão, veiu dele a desaparecer, no ultimo transe, o art. 32, não encontrado no texto da lei. Passou a constituir projeto separado e autonomo...

Em lugar dele se encontra o dispositivo que aquele Deputado propos se incluisse entre as disposições gerais, nesta conformidade: 
Art. 34. - 0 devedor, ou o terceiro que der os seus bens ou animais em garantia da divida, que os desviar, abandonar ou permitir que se depreciem ou venham a perecer, fica sujeito ás penas do depositario infiel.

Paragrafo unico. - Pratica o crime de estelionato e fica sujeito ás penas do art. 338 da Consolidação das Leis Penais aquele que fizer declarações falsas acerca da quantidade, da qualidade e dos carateristicos dos bens ou animais empenhados ou omitir, na escritura, a declaração de estarem eles já sujeitos ao vinculo de outro penhor.

Art. 35. - Entra esta lei em execução trinta dias depois de publicada no Diario Oficial da União, revogadas as disposições em contrario.

Rio de Janeiro, 18 de dezembro de 1936.

"O aumento da taxa de juros até $8 \%$ fatalmente despertará o interesse dos bancos particulares, que, animados pelas facilidades do redesconto, poderâo assim desenvolver os emprestimos pignoraticios á lavoura e pecuaria. gerais :

"Propomos, pois, o seguinte artigo no capitulo das disposições

"Não excederão de $8 \%$ ao ano os juros de obrigações contraidas para o financiamento de trabalhos agricolas e pecuarios, e para a respectiva compra de maquinismos e utensilios, desde que tenham a garantia do penhor rural".

Esse foi o texto que se converteu no do art. 32 da lei, substituido o ultimo adjetivo "rural", qualificativo do penhor, pelo de "agricola", fazendo-se uma restrição sensivel, prejudicial, de certo modo, ao devedor pignoraticio pecuario, não alcançado pelo dispositivo.

Seguiu-se o novo artigo proposto pelo mesmo Deputado:

"A garantia subsidiaria do penhor para a cedula rural ou titulo cujo devedor, aceitante ou emitente exerça a sua atividade na agricultura ou pecuaria ou em industrias derivadas ou conexas, e cujo endossante seja firma bancaria idonea, confere-lhe o direito de redesconto, sem outro limite, em importancia ou garantia, que o estabelecido pelo Conselho da Carteira de Redesconto para as cooperativas e, em um maximo de $50 \%$ dos capitais e fundos de reserva, para cada Banco".

Os outros dois artigos subsequentes vieram a ser os de ns. 34 , 35 e 36 da lei. 
M O D E L O

\title{
ESTADO DE SÃO PAULO
}

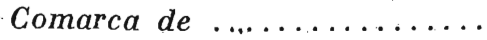 \\ Municipio de .............. \\ Distrito de ................ .. \\ . $\quad \ldots \ldots \quad \ldots \quad \ldots \quad$ Circunscrição
}

N.o. $\quad \cdots$

\section{CEDULA RURAL PIGNORATICIA}

expedida, nos termos da lei n.o....., de .... de .... de 1937, em favor de ................., por efeito da transcriçẫo, sob n.o ...., á pag. . .... do livro n. ${ }^{\circ} \ldots$. . em . . . . de .. .. de 193 , do Cartorio do Registro Imobiliario da Comarca de .... ...... da escritura .... de ... . de ......de 193 , por via da qual ................., brasileiro, agricultor, domiciliado em .........., constituindo-se-lhe devedor da quantia de .......... contos de reis ( $R$ s $\$ 000)$, se obrigou a fazer-lhe o devido pagamento, com os juros de por cento ( \%) ao ano, dando-lhe em penhor os seguintes:

Os $\quad . \quad \ldots$ empenhados se acham depositados em poder do devedor na propriedade agricola denominada

situada nesta comarca e municipio, bairro de .........., distrito de . . ......., e adquirida por escritura de de ...... de 19 , das notas do tabelião (L. N.o , fls. ) desta comarca, transcrita sob n.o..... em de .. de 19

$$
\begin{array}{ll}
\ldots \ldots \text { de } \ldots & \text { de } 19 \\
\text { O oficial, } &
\end{array}
$$


M O D E L O

\title{
ESTADO DE SÃO PAULO
}

\author{
Comarca de \\ Municipio de \\ Distrito de \\ Circunscrição
}

N.o.......

\section{CEDULA RURAL PIGNORATICIA}

expedida, nos termos da lei n. ${ }^{\circ} . \ldots \ldots$ de . . de ....... de 1937, em favor de $\quad . . . . . . . .$. por efeito da transcrição, sob n.o ... ., á pag. ...... do livro n.o . em .. de ..... de 193 , do Cartorio do Registro Imobiliario da Comarca de ........ . da escritura ... de .... de ..... de 193 por via da qual . . . . . ..., brasileiro, agricultor, domiciliado em .. .. ...., constituindo-se-lhe devedor da quantia de .. ..... contos de reis (Rs $\$ 000)$, se obrigou a fazer-lhe o devido pagamento, com os juros de por cento (\%) ao ano, dando-lhe em penhor os seguintes:

Os ........ empenhados se acham depositados em poder do devedor na propriedade agricola denominada ............... situada nesta comarca e municipio, bairro de ........... distrito de ......, ., e adquirida por escritura de de ....... de 19 , das notas do tabelião (L. N.o , fls. ) desta comarca, transcrita sob n.o.... em de ..... de 19

... de de 19

$O$ oficial, $\quad$ o credor, 